\title{
Anaplastic large cell lymphoma associated with breast implants. Importance for the surgeon
}

Linfoma anaplásico de células grandes asociado a implantes mamarios. Importancia pal el cirujano

David Martínez-Ramos ${ }^{*}$, Laura Simón-Monterde², Consuelo Suelves-Piqueres ${ }^{1}$, Raquel Queralt-Martî́and Manuel Laguna-Sastre ${ }^{1}$

${ }^{1}$ Breast Pathology Unit, Department of General and Digestive System Surgery, Hospital Universitario General Castellón; ²Centro de Salud Fernando El Católico, Castellón, Spain

\begin{abstract}
Breast implant-associated anaplastic large-cell lymphoma (BIA-ALCL) is an infrequent disease, although the number of câses has increased in the recent years. BIA-ALCL is revealed during medical screening as an increase in the mammary volume due to periprosthetic effusion or as a capsular mass. Preferred treatment for BIA-ALCL is surgery, with explantation of the prostheses and exeresis of the periprosthetic capsule. Prognosis, after early diagnosis and adequate treatment, is good. The objective of the present work was to review the existing scientific literature on BIA-ALCL and to show the importance o $\overline{\bar{p}}_{\mathrm{E}}$ this type of neoplasia for a successful treatment.

KEY WORDS: Lymphoma anaplastic. Cell large. Implants breast.

\section{Resumen}

El linfoma anaplásico de células grandes asociado a implantes mamarios (BIA-ALCL, breast implant associated-anaplastic large cell lymphoma) es una enfermedad infrecuente, pero el número de casos ha aumentado en los últimos años. Se püede presentar en la consulta del cirujano como un aumento del volumen mamario por derrame periprotésico o como masa ¿apsular. El tratamiento de elección es la cirugía, con explante de las prótesis y exéresis de la cápsula periprotésica. El prönóstico, si el diagnóstico es precoz y el tratamiento es adecuado, es bueno. El objetivo del presente trabajo fue revisar la titeratura científica existente hasta la fecha sobre el BIA-ALCL y poner de manifiesto la importancia que este tipo de neoplasia tiene para el cirujano.
\end{abstract}

PALABRAS CLAVE: Linfoma anaplásico. Células grandes. Implantes mamarios.

\section{Introduction}

The use of breast implants is a common practice in the western world, where these prostheses can be implanted either for esthetic purposes (augmentation mammoplasty) or for reconstructive purposes, either for breast cancer or associated with risk-reduction prophylactic surgeries.

As any implantable device, breast prostheses can develop complications, such as capsular contracture, infections, hemorrhages, seromas, autoimmune phenomena, etc. ${ }^{1}$ So far, no causal relationship has been demonstrated between breast implants and breast

\author{
Correspondence: \\ *David Martínez-Ramos \\ Hospital Univ. General de Castellón \\ Avda. Benicassim, s/n España, \\ C.P. 12004 Castellón, España \\ E-mail: doctormartinezramos@gmail.com
}

Date of reception: 27-03-2018

Date of acceptance: 14-05-2018

DOI: $10.24875 / C I R U E . M 18000070$
Cir Cir. 2018;86:408:413 Contents available at PubMed www.cirugiaycirujanos.com 
cancer. However, since about two decades, a worrying association has been observed between breast implants and an uncommon type of lymphoma: anaplastic large cell lymphoma. This lymphoma has specific and particular characteristics, and thus it has been specifically named breast implant-associated anaplastic large cell lymphoma (BIA-ALCL).

Nearly $60 \%$ of BIA-ALCLs occur in patients undergoing primary breast augmentation, but $40 \%$ occur in patients with breast reconstruction ${ }^{2}$. Although it is true that it is an uncommon situation, the number of reported cases has exponentially increased in recent years. In addition, as it occurs in most neoplasms, the prognosis of this type of lymphomas will depend, to a large extent, on the possibility for adequate surgical treatment to be carried out, which in turn will depend on a correct and early diagnosis. Therefore, the surgeon must be aware of this situation, which will allow for him/her to maintain a high rate of suspicion.

The purpose of this work was to make an update of the status of the BIA-ALCL situation and highlight the importance this type of neoplasm has for the surgeon.

\section{Historical background}

Anaplastic large cell lymphoma (ALCL) was first described in 1985 by Stein et al. ${ }^{3}$ as a non-Hodgkin lymphoma of anaplastic cytology and $\mathrm{Ki}-1$ antigen (CD30) expression. A few years later, in 2008, the World Health Organization included ALCL in the classification of lymphomas, recognizing two main varieties depending on anaplastic lymphoma kinase (ALK) expression: ALK-positive ALCL and ALK-negative $A L C L 4$.

The first association between ALCL and breast implants was established in 1997 by Keech et al. ${ }^{5}$ in a series of 46 cases diagnosed in Australia and New Zealand. Since then, different cases and case series have been described in the literature, with the largest series including no more than 200 cases $^{6-12}$.

In 2011, the US Food and Drug Administration (FDA) warned about the possible risk for developing a type of non-Hodgkin lymphoma associated with the use of breast implants, based on a series of 60 cases reported in the literature ${ }^{13}$. In its report, the FDA only warned about a slight probability of developing ALCL in patients who were bearers of breast prostheses, advising against prosthesis explant if there was no suspicion of this disease. Since 2010, some specific alert measures were instituted in the US. In the latest
FDA report, dated February $2017^{14}$, 359 cases had been recorded in the US, although this agency recognized that there could be under-reporting bias, düplicate presentation of events and lack of information about breast implants total number. Recently, inctuding the BIA-ALCL subtype in the TNM classification for lymphoid neoplasms has been proposed ${ }^{15}$. In Mexico and Latin America, the first documented case was reported by Torres-Rivero et al. ${ }^{16}$ in 2016 , in a 43 -yearold patient.

\section{Incidence}

The exact incidence of BIA-ALCL is still unknown for multiple reasons. On one hand, there is noe an international case registry and neither is it a mahndatory notifiable disease, and thus many cases may have not been reported or, conversely, a single case may have been published on several occasions, by different specialists involved in the diagnostic-therapeutic process. On the other hand, although it has been estimated that 10 million people in the worlotare bearers of breast implants, exact data on this figure are not available, so that everything is based on more or less accurate estimates. Finally, we must admitthat some ignorance about this disease still persists among health professionals themselves, which could lead to underdiagnosis and, therefore, to a falselydow incidence ${ }^{17}$.

In this necessarily prudent context, Doren et alt. ${ }^{8}$, based on 100 cases reported in the USA, estimated an incidence of 2.03 cases per million and year although other authors have substantially increased this estimate to one case per 30,000 women with prostheses per year ${ }^{19,20}$. According to available data, the cyisk for developing ALCL is estimated to be 18.2-67.6-fold higher in those women with breast prostheses than in women without implants. However, in a Danish pôpulation-based cohort study with nearly 20,000 women who were bearers of breast prostheses no single case of BIA-ALCL was found ${ }^{21}$. As previously mentioned, these data are rather indirect and should not be considered conclusive.

\section{Pathogenesis}

The etiopathogenesis of this disease and its risk factors are not exactly known, although the mostrecent data suggest that its occurrence would be related to a local inflammatory process ${ }^{17,22}$. Thus, it could be hypothesized that silicone particles or the implant surface 
would start the inflammatory process that would lead to the development of lymphoma. For other authors, it could be secondary to lymphocytic stimulation by a superinfection in the prosthesis biofilm. In fact, Hu et al. ${ }^{23}$ reported an increase in the prevalence of Ralstonia spp. (a gramnegative opportunistic microorganism) in the capsule of patients with BIA-ALCL in comparison with controls. Something might occur similar to what is observed with MALT-type lymphomas, where chronic inflammation by Helicobacter pylori is well documented. Other theories point to autoimmune phenomena, genetic predisposition or history of capsular trauma ${ }^{19}$. However, at this point, it is still early to assume any of these hypotheses (or the combination thereof) as being valid and more studies are needed to allow establishing more accurate etiopathogenic mechanisms.

\section{Types of prosthetic implants involved}

The first cases of ALCL were related both to smooth and textured implants, although, recently, texturized prostheses have been reported to be more commonly associated with BIA-ALCL ${ }^{18}$. Furthermore, both silicone and saline implants have been associated with the appearance of lymphoma, with a predominance in silicone prostheses (39 vs. $61 \%)^{17,19}$. However, it should be considered that, especially in reconstructive surgery cases, many patients have been carriers of different implants and replacements (expanders or definitive prostheses), and therefore it is difficult to establish the type of causative prosthesis. In addition, the prosthesis texturing process varies from one manufacturer to another, and thus it is even more complicated to establish conclusive associations. On the other hand, cases have been reported involving different manufacturers, although nearly all studies have been carried out in the USA and, therefore, the commercialized brands of that country have been more carefully studied.

\section{Diagnostic suspicion and clinical manifestations}

There are two BIA-ALCL basic forms of presentation and that should alert the surgeon. On one hand, the most common form of clinical presentation is as a late relapsing periprosthetic seroma (with breast volume abrupt increase), and the second is as a mass in the periprosthetic capsule ${ }^{24,25}$. Other less common manifestations include palpable axillary adenopathy, capsular contracture, skin lesions ${ }^{26}$ and type B symptoms (fever, adenopathies, night sweats and fatigue). Nearly $15 \%$ of cases have metastases to axillary lymph nodes, very rarely bilateral, with less than 10 reported cases $^{27}$.

In the systematic review carried out by Leberfinger et al. ${ }^{20}$, mean age for the occurrence of $A L C L$ was 51 years, with women with reconstruction being older than those operated for esthetic purposes (with a mean of 57 versus 46 years, respectively), possibly because women operated for esthetic purposes are younger from the start. It is important highlighting that, in most western countries, these age ranges are included in the population screening programs, which should also be considered in these women during the screening tests. On the other hand, mean time since the prosthesis implantation until the onset of lymphoma is around 10 years in most series ${ }^{2,20}$.

\section{Diagnosis}

The first complementary exploration for a patient bearer of breast prosthesis presenting with breast volume abrupt increase is usually an ultrasound, which will allow identifying the presence of periprosthetic fluid, as well as the existence of capsular masses. In addition, ultrasound can guide a fine needle aspiration biopsy of periprosthetic fluid for analysis. The appearance of this fluid is usually turbid in case of BIA-ALCL. Cytological analysis of the extracted fluid will guide the diagnosis, which will be confirmed by immunohistochemical analysis. Obviously, it is important for the surgeon to suspect this disease in order for him/her to request a directed immunohistochemical analysis of the fluid, since BIA-ALCLs are positive for CD30, positive for epithelial membrane antigens and ALK-negative. Capsular biopsy is not indicated for all cases of periprosthetic effusion, $\_$but the capsule must be histopathologically analyzzed when surgically excised. Similarly, if a suspicious lymph node is appreciated during surgery, it should be resected for examination ${ }^{27}$.

Several management algorithms have been proposed in case of BIA-ALCL suspicion, according to different countries and health systems ${ }^{2,27,28}$, altheigh all concur on the need to perform an ultrasound in case of suspicion, as well as cytological analysis of the periprosthetic fluid. Other imaging tests, especially magnetic resonance imaging, can also be usëful. Thus, according to the results obtained by Adrada et al. ${ }^{29}$, the sensitivity to detect effusion was $84 \%$ for 


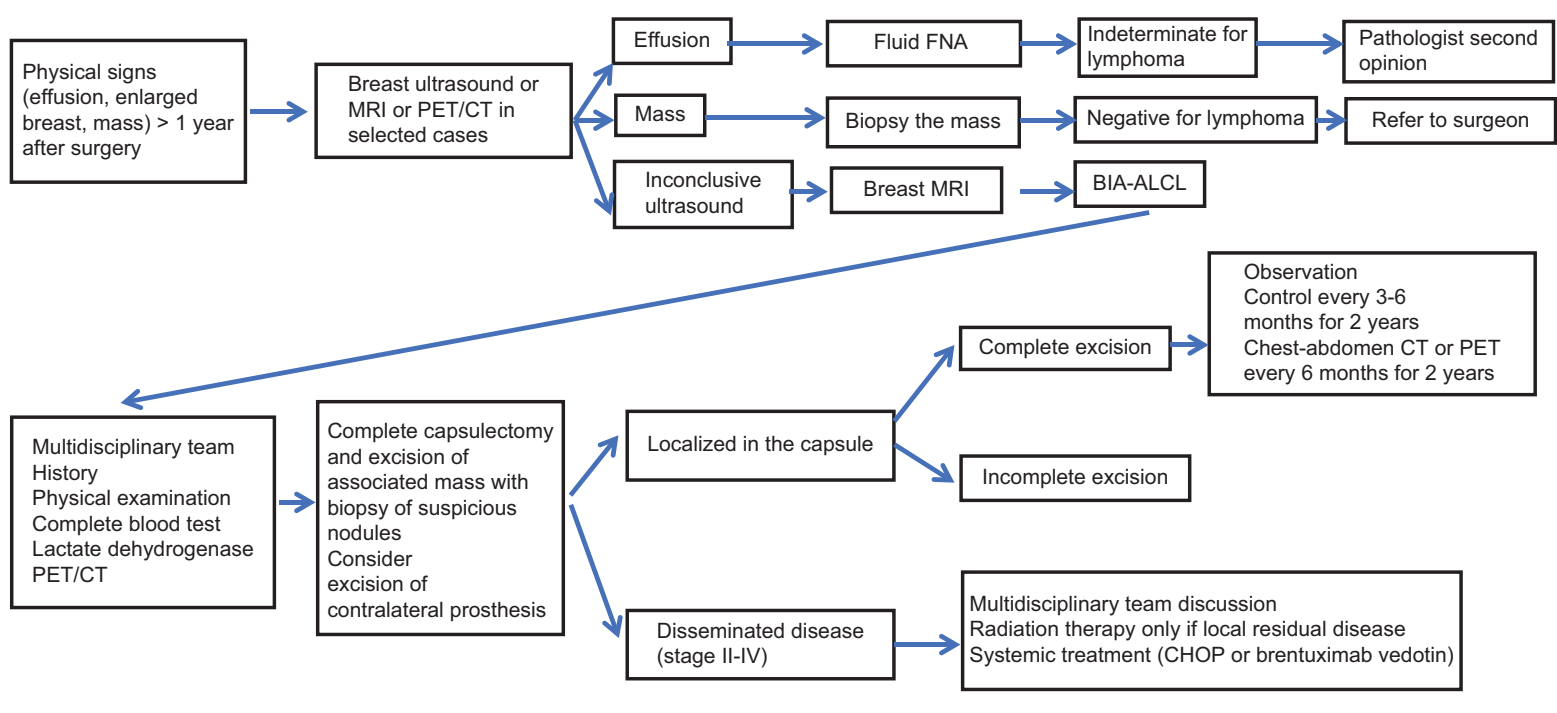

Figure 1. Leberfinger et al. ${ }^{20}$ algorithm, proposed and adapted for the diagnosis and treatment of breast implant-associated anaplastic large cell lymphoma. BIA-ALCL: breast implant-associated anaplastic large cell lymphoma; CHOP: cyclophosphamide, hydroxydaunoubicin, vincristine, prednisone; FNA: fine needle aspiration; PET: positron-emission tomography; MRI: magnetic resonance imaging; CT: computed tomography

ultrasound, $82 \%$ for magnetic resonance imaging, $55 \%$ for computed tomography (CT) and $38 \%$ for positron-emission tomography (PET). The sensitivity of mammography for the detection of any abnormality (without discriminating between seroma and mass) was $73 \%$, while specificity was $50 \%$. It should be noted that this data were obtained by analyzing the results of 40 cases, some of them from the literature (not from the authors themselves), with the limitations this implies.

Finally, the systemic disease extension study of choice should be PET/CT, ideally after surgery (once the lesion has been removed) in order to reduce the risk of false-positives ${ }^{27.30}$.

\section{Staging}

Systemic anaplastic large cell lymphoma (not associated with breast implants) is an uncommon and aggressive lymphoma with a dismal prognosis, which requires intensive systemic treatment and that is generally staged with the Ann Arbor classification ${ }^{31}$. However, this classification might not be suitable for BIA-ALCL, since it would over-stage it and, therefore, these patients, who in principle have a much better prognosis, would be over-treated ${ }^{2}$. For this reason, Clemens et al. $^{15}$ have proposed a specific modification for BIA-ALCL that recognizes a very low risk group with intraluminal disease and differentiates it from a second high-risk group with extraluminal disease that would benefit from systemic treatment.

\section{Treatment}

Most importantly, the surgeon should know that unlike most lymphomas, BIA-ALCL it is often curable exclusively with surgery ${ }^{19}$. Although there is no established treatment protocol, surgery seems to be clearly the treatment of choice when the disease is localized $^{15,27}$, which occurs in most cases. According to current scientific evidence, optimum treatment should include prosthesis removal, complete capsulectomy, resection of all lymphoma implants with margins (in $\uparrow 2$ and T 3-infiltrating cases) and resection of any süspicious adenopathy ${ }^{19}$. Currently, there are no data to recommend mastectomy, sentinel node selectivè biopsy or axillary lymphadenectomy. It is important to evaluate the contralateral breast, since nearly $5 \%$ of cases had lymphoma in the capsule, and the decision should be taken in agreement with the patient after being duly informed. Placement of a new prosthesis is not recommended after BIA-ALCL diagnosis, and there are not data available to make recommendations on eventual subsequent breast reconstruction ${ }^{15,25}$.

As for adjuvant treatments, there is little evidence for cases where complete removal of the lesions is not.possible or cases with distant disease, since there are no clinical trials available. If there is surgical margin involvement, unresectable disease or chest wall invașion, radiation therapy can be beneficial. If there is disseminated disease, systemic treatment is indicated with regimens similar to those used for peripheral T lymphoma, although data are inconclusive and new studies are 
needed. The most widely used chemotherapy treatment protocol is the CHOP regimen (cyclophosphamide, doxorubicin hydrochloride, vincristine sulfate and prednisone). However, in the absence of sufficient scientific evidence, the need to individualize treatments seems clear while awaiting new studies ${ }^{19}$. Recently, Leberfinger et al. ${ }^{20}$ have proposed a management algorithm for these patients, whose adaptation is shown in figure 1.

\section{Prognosis}

The prognosis of this type of lymphoma is highly favorable, except in some cases that can be especially aggressive. Nodular lesions, axillary lymph node involvement, bilateral involvement and infiltrative pattern in the capsule histology have been associated with more aggressive behavior. Prognosis is better with complete surgical excision of the capsule than with partial resections, both for overall survival and disease-free interval ${ }^{15}$. Some authors have considered that the presence of lymphoma in the periprosthetic fluid is a different situation to that of a tumor with infiltrating mass, but there is not enough evidence for such an assertion ${ }^{17}$. In most series, follow-up time is still short, although some authors have reported follow-up periods of up to 20 years $^{32}$. Current recurrence rate with complete lesion resection is $6-11 \%$, and mean overall survival has been $12-13$ years ${ }^{19}$. Thus far, among the 359 cases reported to the FDA, nine died as a consequence of their disease ${ }^{14}$.

As for follow-up, according to the National Comprehensive Cancer Network recommendations ${ }^{27}$, if tumor resection has been complete and there is no residual disease, it should be carried out every 3-6 months through history and physical examination for at least 2 years. In these 2 years, chest, abdominal and pelvic CT with contrast, or PET-CT, should be added every 6 months. After 2 years, follow-up will depend on patient clinical manifestations ${ }^{27}$.

\section{Informed consent}

No one questions anymore that informed consent is one more part of any surgical act. It is a right of any patient to have all the necessary information for appropriate decision making, as well as to know the possible risks of the surgery he/she is going to undergo. For this reason, the consulted literature unanimously agrees that BIA-ALCL is an uncommon disease, but that all candidates for prosthesis implantation should be informed about it ${ }^{2,33}$. The purposes of this information are three: 1) to inform the patients about the existence of this rare disease; 2) to inform on the usual form of presentation in oṕder to enable early diagnostic; and 3) to inform the ppa- $^{-}$ tients about the existing treatment options in case it occurs.

\section{Conclusion}

BIA-ALCL is an uncommon disease, but the number of cases has increased in recent years. It is imporfant for the surgeon and the breast specialist be aware of its existence, since early diagnosis and treatmentean entail the cure of the patient.

\section{References}

1. Rocco N, Rispoli C, Moja L, Amato B, lannone L, Testa S, et al. Diffèrent types of implants for reconstructive breast surgery. Cochrane Database Syst Rev. 2016;(5):CD010895.

2. Johnson L, O'Donoghue JM, McLean N, Turton P, Khan AA, Turner SD. Breast implant associated anaplastic large cell lymphoma: the UK experience. Recommendations on its management and implications forinformed consent. Eur J Surg Oncol. 2017;43:1393-401.

3. Stein H, Mason DY, Gerdes J, O'Connor N, Wainscoat J, Pallesen G, et al. The expression of the Hodgkin's disease associated antigen $\mathrm{Ki}-1$ in reactive and neoplastic lymphoid tissue: evidence that Reed-Sternberg cells and histiocytic malignancies are derived from activated lymphoid cells. Blood. 1985;66:848-58.

4. Sathyanarayanan V, Lokesh KN, Lakshmaiah KC, Govind Babu K, Lokanatha D, Suresh Babu MC, et al. Anaplastic lymphoma kinase (ALK) positive anaplastic large cell lymphoma (ALCL) of breast in a patient without a breast implant. Ann Saudi Med. 2014;34:551-4.

5. Keech JA Jr, Creech BJ. Anaplastic T-cell lymphoma in proximity to a saline-filled breast implant. Plast Reconstr Surg. 1997:100:554-5.

6. Nogueira Batista B, Garicochea B, Nunes Aguilar VL, Carvalho-FM, Millan LS, Pires Fraga MF. Report of a case of anaplastic large cell lymphoma associated with a breast implant in a Brazilian patient.Rev Bras Cir Plast. 2017:32:445-9.

7. Letter H, Rop B, Edison MN, Turner P. Breast implant-associatedanaplastic large cell lymphoma: a case report and literature review. Cureus. 2016;8:e546.

8. Hwang MJ, Brown H, Murrin R, Momtahan N, Sterne GD. Breast implant-associated anaplastic large cell lymphoma: a case report and literature review. Aesthetic Plast Surg. 2015;39:391-5.

9. Evren S, Khoury T, Neppalli V, Cappuccino H, Hernández-Ilizalitureri FJ, Kumar P. Breast implant-associated anaplastic large cell lymphoma (ALCL): a case report. Am J Case Rep. 2017;18:605-10.

10. Zimmerman A, Locke FL, Emole J, Rosa M, Horna P, Hoover S, Et al. Recurrent systemic anaplastic lymphoma kinase-negative anaplastic large cell lymphoma presenting as a breast implant-associated fesion. Cancer Control. 2015;22:369-73.

11. Popplewell L, Thomas SH, Huang Q, Chang KL, Forman SJ. Primary anaplastic large-cell lymphoma associated with breast implants. Qeuk Lymphoma. 2011;52:1481-7.

12. Xu J, Wei S. Breast implant-associated anaplastic large cell lymphoma: review of a distinct clinicopathologic entity. Arch Pathol Lab Med. 2014;138:842-6.

13. Center for Devices and Radiological Health U.S. Food and Drug-Anaplastic large cell lymphoma (ALCL) in women with breast implant liminary FDA findings and analyses. 2011. (Consultado el 14 de dieliembre de 2017.) Disponible en: https://www.fda.gov/MedicalDevices/ ProductsandMedicalProcedures/ImplantsandProsthetics/Breast/mptants/ ucm239995.htm.

14. Center for Devices and Radiological Health U.S. Food and Drug. Breast implant-associated anaplastic large cell lymphoma (BIA-ALCL). 2017. (Consultado el 14 de diciembre de 2017.) Disponible en: https://www. fda.gov/medicaldevices/productsandmedicalprocedures/implantsandprosthetics/breastimplants/ucm239995.htm.

15. Clemens MW, Medeiros LJ, Butler CE, Hunt KK, Fanale MA, Horwitz S, et al. Complete surgical excision is essential for the management of patients with breast implant-associated anaplastic large-cell lymphoma. J Clin Oncol. 2016;34:160-8. 
16. Torres-Rivero C, Ramos-Gallardo G, Nambo-Lucio MJ, Vaquero-Pérez MM. Primer caso en México y América Latina de linfoma anaplásico de células gigantes en paciente con implantes mamarios. Cir Plast. Iberolatinoam. 2016;42:175-80.

17. O'Neill AC, Zhong T, Hofer SOP. Implications of breast implant-associated anaplastic large cell lymphoma (BIA-ALCL) for breast cancer reconstruction: an update for surgical oncologists. Ann Surg Oncol. 2017;24:3174-9.

18. Doren EL, Miranda RN, Selber JC, Garvey PB, Liu J, Medeiros LJ, et al U.S. epidemiology of breast implant-associated anaplastic large cell lymphoma. Plast Reconstr Surg. 2017;139:1042-50.

19. Kaartinen I, Sunela K, Alanko J, Hukkinen K, Karjalainen-Lindsberg ML, Svarvar C. Breast implant-associated anaplastic large cell lymphoma — from diagnosis to treatment. Eur J Surg Oncol. 2017;43:1385-92.

20. Leberfinger AN, Behar BJ, Williams NC, Rakszawski KL, Potochny JD Mackay DR, et al. Breast implant-associated anaplastic large cell lymphoma: a systematic review. JAMA Surg. 2017;152:1161-8.

21. Vase MØ, Friis S, Bautz A, Bendix K, Sørensen HT, d'Amore F. Breast implants and anaplastic large-cell lymphoma: a Danish population-based cohort study. Cancer Epidemiol Biomarkers Prev. 2013;22:2126-9.

22. George EV, Pharm J, Houston C, Al-Quran S, Brian G, Dong H, et al. Breast implant-associated ALK-negative anaplastic large cell lymphoma: a case report and discussion of possible pathogenesis. Int $\mathrm{J}$ Clin Exp Pathol. 2013;6:1631-42.

23. Hu H, Johani K, Almatroudi A, Vickery K, Van Natta B, Kadin ME, et al. Bacterial biofilm infection detected in breast implant-associated anaplastic large-cell lymphoma. Plast Reconstr Surg. 2016;137:1659-69.

24. Fernández-Sobrino I, Cordones-Guerrero JJ, Benítez-Dupin O, Cornejo-Ladrero Jl, Lobo-Samper F. Palpable mass as an atypical presentation of breast implants-associated anaplastic large cell lymphoma. Cir Plast Iberolatinoam. 2017;43:129-35.
25. Clemens MW, Nava MB, Rocco N, Miranda RN. Understanding-rare adverse sequelae of breast implants: anaplastic large-cell lymphoma, late seromas, and double capsules. Gland Surg. 2017;6:169-84.

26. Alcalá R, Llombart B, Lavernia J, Traves V, Guillén C, Sanmartín O. Skin involvement as the first manifestation of breast implant-associated anaplastic large cell lymphoma. J Cutan Pathol. 2016;43:602-8.

27. Clemens MW, Horwitz SM. NCCN consensus guidelines for the diagnosis and management of breast implant-associated anaplastic large cell lymphoma. Aesthet Surg J. 2017;37:285-9.

28. Ramos-Gallardo G, Cuenca-Pardo J, Rodríguez-Olivares E, Tribarren-Moreno R, Contreras-Bulnes L, Vallarta-Rodríguez A, et al. Breast implant and anaplastic large cell lymphoma meta-analysis. J Invest Surg. 2017;30:56-65.

29. Adrada BE, Miranda RN, Rauch GM, Arribas E, Kanagal-Shamanna R, Clemens MW, et al. Breast implant-associated anaplastic large celhlymphoma: sensitivity, specificity, and findings of imaging studies in 44 patients. Breast Cancer Res Treat. 2014;147:1-14.

30. Acevedo-Báñez I, García-Gómez FJ, Jiménez-Granero P, Oarrillo-Cruz E, Pérez-López O, Borrego-Dorado I. 18F-FDG-PET/CT in implant-associated anaplastic large cell lymphoma of the breast. $\mathrm{Br} \sqrt{\mathrm{H}} \mathrm{ae}-$ matol. 2015;169:1.

31. Laurent C, Delas A, Gaulard P, Haioun C, Moreau A, Xerri L, et al. Breast implant-associated anaplastic large cell lymphoma: two distinct olinicopathological variants with different outcomes. Ann Oncol. 2016;27:306-14.

32. Miranda RN, Aladily TN, Prince HM, Kanagal-Shamanna R, de Jong D, Fayad LE, et al. Breast implant-associated anaplastic large-cell lymphoma: long-term follow-up of 60 patients. J Clin Oncol. 2014;32:114-20.

33. Clemens MW, Miranda RN, Butler CE. Breast implant informed consent should include the risk of anaplastic large cell lymphoma. Plast Reconstr Surg. 2016;137:1117-22. 